\title{
Poetyka konceptu Macieja Kazimierza Sarbiewskiego w kręgu historii idei
}

\author{
Anna Kołos
}

\section{Wprowadzenie}

Współczesne rozumienie poezji zostało dalece ukształtowane przez długotrwały proces „lirycyzacji” ${ }^{1}$, zapoczątkowany w okresie przedromantycznym, a liczący sobie około dwustu pięćdziesięciu lat wciąż żywej historii. Jak można sądzić:

W toku tego nierównego procesu projektowane gatunki wierszowane, które dotychczas należały do neoklasycystycznych taksonomii, określonych wspólnot czy szczególnych trybów cyrkulacji, stopniowo zawężały się do coraz bardziej i bardziej abstrakcyjnej kategorii poezji, utożsamionej z liryką².

Ten ogólnikowo zasygnalizowany fenomen, wraz z częściowo pokrewnymi zagadnieniami, jak Kantowska idea "geniuszu” czy kategoria „oryginalności”, zdaje się trafnie wskazywać na specyfikę długiej historii „lirycznej” praktyki czytania, będącej zarówno częścią autonomicznie postrzeganej historii literatury, jak i społecznych uwarunkowań odbioru. Z takiej perspektywy szeroko pojętą formację poromantyczną oddziela od przednowoczesnych neoklasycystycznych (choć nie tylko) taksonomii i systematyzacji, które najczęściej wiążemy z pojęciem sformułowanej poetyki historycznej przepaść percepcyjna. O ile swoistą atrakcyjność dla czytelnika współczesnego zachowują utwory Sępa-Szarzyńskiego, Rytmy Sebastiana Grabowieckiego czy sonety angielskich metafizyków, bliższe dramatyzmowi poetyckiej ekspresji, z którą z czasem utożsamiono lirykę, o tyle dawne poetyki normatywne zdają się budować obraz martwego kanonu, który stanowić może jedynie obiekt poznania historycznego, sprowadzonego w swojej prymarnej funkcji do odtworzenia reguł literackiego rzemiosła. W świetle długiego trwania romantycznej koncepcji pisarskiej musi bowiem kuriozalnie brzmieć takie choćby założenie Scaligera: „Pauca licere perfecto poetae”3 („niewiele wolno doskonałemu poecie"). Czy możliwe jest dzisiaj Winckelmannowskie odczytanie dawnego kanonu na potrzeby stworzenia aktualnego programu literackiego, przekucie antykwarycznych fascynacji na

\footnotetext{
${ }^{1}$ V. Jackson, Dickinson's Misery. A Theory of Lyric Reading, Princeton-Oxford 2005, s. 6-9.

${ }^{2}$ The Lyric Theory Reader. A Critical Anthology, red. V. Jackson, Y. Prins, Baltimore 2014, s. 452. Przekł. - A.K.

${ }^{3}$ J.C. Scaliger, Poetices libri septem, edition secunda, [Genève] 1581, s. 816.
} 
poetykę zdolną do wzbudzenia przeżycia estetycznego we współczesnym czytelniku? $\mathrm{Na}$ to pytanie nie podejmuje się odpowiedzi, choć niewątpliwie sceptycyzm pozostaje uzasadniony.

Nie wykraczając natomiast poza kompetencje literaturoznawcy, można zasadnie roztrząsać znaczenie drugiego członu sformułowania „poetyka historyczna”, poddać mianowicie refleksji, jaką historię rekonstruować na podstawie dawnych teorii dzieła literackiego. W szczególności w obliczu zwrotu kulturowego w badaniach humanistycznych kategoria historyczności odsłania swój wielowymiarowy i niejednoznaczny charakter, przestaje odnosić się jedynie do - bądź co bądź dokonanego już - rozpoznania dawnych zaleceń estetycznych i teoretycznoliterackich, badania ich recepcji oraz wpływu na kształtowanie się gatunków i wzorców. I chociaż historia literatury nawet przez zagorzałych zwolenników przekonania o autonomiczności dzieła literackiego, które legło u podstaw profesjonalizacji dyskursu, nigdy nie była uprawiana w próżni kulturowej, pomijającej związki tekstu z innymi dziedzinami twórczości czy warunkami społeczno-politycznymi, współczesne rozumienie przedmiotu poznania jako „literacko-kulturowego konstruktu” czy „wielowarstwowego konkretu"4, domaga się postawienia kwestii owych zależności w centrum refleksji. Jaki obszar historii może zatem uczynić przedmiotem analizy kontekstowej badacz sformułowanych poetyk przeszłości? W niniejszym artykule proponuję wpisać dawny tekst teoretycznoliteracki w szeroko pojętą historię intelektualną, co pozwala na śledzenie dawnych koncepcji twórczych, które z samej swojej natury rodziły się na styku arbitralnie separowanych dziedzin myśli, jakimi były między innymi literatura, filozofia czy teologia, służące budowaniu wielowymiarowej wizji rzeczywistości.

O ile współcześni teoretycy poetyki historycznej - rozpatrywanej jednak zwykle na polu twórczości nowoczesnej - mówią o dwóch możliwych stanowiskach wobec historii kultury, mianowicie o czytaniu tekstu „od środka na zewnątrz" (inside out) i „od zewnątrz do środka” (outside in) ${ }^{5}$, o tyle klarowność podziału metod na poziomie teoretycznym, pomijając Derridiańską z ducha wątpliwość co do dystynkcji między wnętrzem i zewnętrzem, nie przekłada się na praktykę, która zawsze w mniejszym lub większym stopniu będzie zapętlać oba spojrzenia na tekst ${ }^{6}$. Kultura dawna, której dalekie były idee autonomii dyscyplin, w szczególnym stopniu wymaga tak rozumianego, obustronnego dialogu.

\section{Koncept jako element poetyki i narzędzie poznawcze}

Chociaż każdy szanujący się student polonistyki wymieni na bezdechu klasycznych autorów poetyk sformułowanych, Arystotelesa, Horacego, Pseudo-Longinusa, a spośród nowożytnych Scaligera, Boileau czy - wreszcie - Dmochowskiego, manierystyczne i barokowe lub - szerzej - nieklasyczne teorie literackie wydają się pozostawać nieco w cieniu tych wielkich nazwisk. Na taki stan rzeczy z pewnością wpływ miała autorytatywna krytyka klasyków, jak również dawniejsza praktyka badawcza filologów, którzy nie stronili od opatrywania barokowych poetyk mianem „dziwactw” czy „figli”. Wśród wczesnosiedemnastowiecznych rozpraw, powstałych na styku oddziaływania poetyk renesansowych, kultury potrydenckiej i barokowych koncepcji twórczych na szczególną uwagę zasługuje propozycja teoretyczna Macieja Kazimierza Sarbiewskiego (1595-1640), którego bez cienia przesady należałoby uznać za najbardziej znanego na arenie europejskiej pisarza polskiego

\footnotetext{
${ }^{4}$ R. Nycz, Kulturowa natura, słaby profesjonalizm. Kilka uwag o przedmiocie poznania literackiego i statusie dyskursu literaturoznawczego, [w:] tegoż, Poetyka doświadczenia. Teoria - nowoczesność - literatura, Warszawa 2012, s. 101.

5 Takie przekonanie towarzyszyło organizatorom konferencji „Poetic Genre and Social Imagination: Pope to Swinburne" na University of Chicago w 2014 roku.

${ }^{6}$ Y. Prins, What Is Historical Poetics?, „Modern Language Quarterly” 2016, vol. 77, nr 1, s. 14.
} 
pochodzenia do czasów spektakularnej kariery Henryka Sienkiewicza. Chrześcijański Horacy, wyróżniony przez papieża Urbana VIII jako poeta laureatus, zasłynął głównie jako autor parodii (w znaczeniu staropolskim) ód rzymskiego twórcy ${ }^{7}$, orędownik chrystianizacji antyku ${ }^{8}$ i kodyfikator „poezji doskonałej” (De perfecta poesi), w której łączył podstawy estetyki Arystotelesa z iście barokowym kreacjonizmem poetyckim ${ }^{9}$. Osobne miejsce w curriculum Sarbiewskiego zajmuje zagadnienie epigramatu, gatunku żywo rozwijającego się w renesansie, lecz pomimo antycznej proweniencji dalekiego od doskonałości zagwarantowanej dla epopei ${ }^{10}$. Praktyka epigramatyczna jezuity dopiero w ostatnich latach zaczyna być wydobywana z zapomnienia ${ }^{11}$, którego podstawy pozwala zrozumieć Władysław Syrokomla, romantyczny tłumacz łacińskich wersów, wyrażający opinię, bez cienia wątpliwości obrazującą nieprzystawalność barokowej poetyki do późniejszych gustów literackich:

Epigrammata Sarbiewskiego są wszystkie niemal w guście Jezuickim, gdzie myśl skoszlawiona nienaturalnymi figurami sili się na dowcip naciągany [...] słowem epigrammata Sarbiewskiego są wyrazem psującego się smaku w jego epoce... ${ }^{12}$.

Wszystkie argumenty wykorzystane przez romantyka w XIX wieku utrwaliła już formacja klasycystyczna. W 1674 roku Boileau bronił francuskiej wymowy przed „fałszywym blaskiem” mody na obce pointy, która przywędrowała z Włoch ${ }^{13}$, a sto lat później (1788) Dmochowski uskarżał się na przebrzmiałą poetykę:

Dawniej epigrammatów duch się zbyt rozszerzył,

Ledwie nie każdy niemi rozum człeka mierzył.

Lecz wedle nich najwięcej gryzły pióra szkoły.

Jakież to dla czczych były ucinków mozoły:

Czemu na białym koniu jeździł Jerzy święty?

Jak głowę swą całował Dyjonizy ścięty?

Wymowa w epigrammach szukała okrasy

\footnotetext{
${ }^{7} \mathrm{Na}$ ten temat zob. m.in. E. Buszewicz, Sarmacki Horacy i jego liryka. Imitacja-gatunek - styl. Rzecz o poezji Macieja Kazimierza Sarbiewskiego, Kraków 2006.

${ }^{8} \mathrm{Na}$ ten temat zob. E. Sarnowska-Temeriusz, Świat mitów i świat znaczeń. Maciej Kazimierz Sarbiewski i problemy wiedzy o starożytności, Wrocław 1969; P. Urbański, Theologia fabulosa. Commentationes sarbievianae, Szczecin 2000; A.W. Mikołajczak, Antyk w poezji Macieja Kazimierza Sarbiewskiego, Poznań 1994.

${ }^{9}$ Zob. E. Sarnowska, Teoria poezji Macieja Kazimierza Sarbiewskiego, [w:] Studia z teorii i historii poezji. Seria pierwsza, red. M. Głowiński, Wrocław 1967, s. 126-147.

${ }^{10}$ Scaliger poświęcił sporo uwagi epigramatom, jednak klasyfikował je podług kategorii retorycznych. Zob. M. Piskała, „Nimis poeta”. Obraz grafomana w dawnej epigramatyce, „Śląskie Studia Polonistyczne” 2013, nr 2 (4), s. 175; R. Krzywy, Poezja staropolska wobec genologii retorycznej. Wprowadzenie do problematyki, Warszawa 2014, s. 25. Więcej o poetyce Scaligera: E. Sarnowska, Główne problemy „Poetyki” Juliusza Cezara Scaligera, „Studia Estetyczne” 1966, t. 3, s. 144-162.

${ }^{11}$ Znamiennym sygnałem wzrostu zainteresowania epigramatyką Sarbiewskiego było wydanie w 2003 roku pierwszej edycji krytycznej Epigrammatum liber w serii „Biblioteki Pisarzy Staropolskich”: M.K. Sarbiewski, Epigrammatum Liber. Księga epigramatów, wyd. i przeł. M. Piskała, D. Sutkowska, Warszawa 2003. Z opracowań zob. m.in. M. Łukaszewicz-Chantry, Epigramy Macieja Kazimierza Sarbiewskiego w świetle jego teorii poetyckiej, „Pamiętnik Literacki” 2000, nr 91/4, s. 7-14; J. Musiał-Zaborowska, Epigramy Macieja Kazimierza Sarbiewskiego, Pułtusk-Warszawa 2006; M. Piskała, Boże miłości i wstydliwe dowcipy. Studia nad epigramatyczna twórczością Macieja Kazimierza Sarbiewskiego i Alberta Inesa, Warszawa 2009; A. Kołos, „Fides quaerens intellectum”. Wiara i rozum w barokowym konceptyzmie Macieja Kazimierza Sarbiewskiego i Stanisława Herakliusza Lubomirskiego, Lublin 2013.

${ }^{12}$ W. Syrokomla, Poezyje ks. Macieja Kazimierza Sarbiewskiego, Dział III. Pienia liryczne i opisowe, Wilno 1851, s. 231232. Cyt. za: M. Piskała, D. Sutkowska, Wprowadzenie do lektury, [w:] M.K. Sarbiewski, Epigrammatum Liber. Księga epigramatów, s. 5.

${ }^{13}$ Zob. D. Gostyńska, Retoryka iluzji. Koncept w poezji barokowej, Warszawa 1991, s. 300.
} 
I kaznodziejskie niemi pstrzyły się hałasy.

Stąd wszystko się popsuło, gust dobry zaginął

I nim do nas powrócił - wiek cały upłynął.

Lubią rymy dowcipność, lecz niezbyt wytworną;

W igraszkach słów masz tylko ozdobę pozorną.

Ściągnij w jedno myśl dobrą wraz z rymem obierze,

A wtenczas epigramma swój poklask odbierze.

(Franciszek Ksawery Dmochowski, Sztuka rymotwórcza, II, w. 175-188) ${ }^{14}$

O ile konceptyczna twórczość epigramatyczna Sarbiewskiego długo czekać musiała na należną jej waloryzację, o tyle jednak teoretyczny traktat De acuto et arguto (O poincie i dowcipie) zajmuje w tradycji badań literackich wysoką pozycję z uwagi na dojrzały i systematyczny wykład poetyki ${ }^{15}$. Pointa należała do pojęć zbliżonych do enigmatycznej niewyrażalności je ne sais quoi, która opanuje dyskusje o smaku w drugiej połowie XVII wieku. Jak pisał Dominique Bouhours w 1671 roku: „il est bien plus aisé de le sentir que de le connaître”16 („łatwiej się to czuje, niż rozumie"). Jeśli istotą dowcipnego konceptu, podobnie jak smaku, jest afektywność (delectare), zrozumiała jest trudność w uchwyceniu pojęcia w kategoriach stricte racjonalnych ${ }^{17}$. Autorytet starożytnych w tym przypadku nie mógł stanowić pomocnego punktu odniesienia, a wyrwane z kontekstu zdanie Horacego z Listu do Pizonów o dowcipnym zestawieniu słów nie tłumaczyło istoty zagadnienia.

Sarbiewski jednak z zaskakująco wysoko rozwiniętym zmysłem analitycznym zdołał sformułować słynną, wielokrotnie powtarzaną definicję:

Pointa jest to mowa, w której zachodzi zetknięcie się czegoś niezgodnego i zgodnego, czyli jest w słownym wypowiedzeniu zgodną niezgodnością lub niezgodną zgodnością. [Acutum est oratio continens affinitatem dissentanei et consentanei, seu dicti concors discordia vel discors concordia] ${ }^{18}$.

Objaśnienie, choć jednocześnie względnie klarowne i konceptycznie oksymoroniczne samo w sobie, nie przesądza jeszcze o nowatorstwie autora, najciekawszym bowiem składnikiem rozprawy jest opracowanie graficznego modelu akuminu. Ujmując rzecz w skrócie, Sarbiewski przedstawia epigramat jako trójkąt równoramienny, którego podstawę stanowi temat (materia), zaś dwa boki odpowiadają przeciwstawnym sobie myślom wywiedzionym $\mathrm{z}$ tematu (consentaneum i dissentaneum). Wierzchołek figury (acutum, czyli „ostrze”), jak nieuchronnie każe geometria, stanowi punkt przecięcia dwóch boków, w którym następuje pointa, czyli zespolenie wprowadzające „zgodną niezgodność” vel „niezgodną zgodność”. Wszak łacińskie określenie conceptus stanowi derywat czasownika concipere, który oznacza również „łączyć”, „jednoczyć”19.

${ }^{14}$ F.K. Dmochowski, Sztuka rymotwórcza. Poema we czterech pieśniach, Wilno 1820, s. 47.

${ }^{15}$ Tkwi w tej niewspółmierności ocen wobec praktyki twórczej i teorii paradoks, bowiem De acuto et arguto, podobnie jak inne pisma teoretyczne, nie zostały wydane za życia autora. Epigramaty natomiast, publikowane wraz z Lyricorum libri tres, cieszyły się ogromną popularnością w Europie.

${ }^{16}$ D. Bouhours, Les entretiens d'Ariste et d'Eugène, nouvelle edition, a Paris 1741, s. 312.

${ }^{17}$ Zob. T. Parker, Volition, Rhetoric, and Emotion in the Work of Pascal, New York-London 2008, s. 187.

${ }^{18}$ M.K. Sarbiewski, De acuto et arguto. O poincie i dowcipie, przeł. i oprac. S. Skimina, [w:] tegoż, Wykłady poetyki (Praecepta poetica), Wrocław 1958, s. 5.

${ }^{19}$ Zob. D. Gostyńska, Retoryka iluzji, s. 5. 
Teoria została oddana przez autora $\mathrm{z}$ iście strukturalistycznym zacięciem, tym bardziej że w początkowej części traktatu Sarbiewski odżegnuje się od innych, znanych mu definicji pointy, pośród których pojawia się również eksplikacja psychologiczna ${ }^{20}$, mówiąca o wywołaniu efektu zaskoczenia. Jezuita zastrzega jednak, że zjawisko niespodzianki wymaga czynnego udziału czytelnika w procesie dopełnienia znaczenia akuminu, podczas gdy definicja powinna całość sensu pozostawiać po stronie autora/dzieła:

[...] do niespodzianki jako takiej dołącza się jeszcze sam czytelnik, natomiast pointa tak się mieści i tkwi w powiedzeniu, że gdy idzie o nią samą, nie zależy od czytelnika. Bez wyjątku bowiem pointa jest płodem mówiącego ${ }^{21}$.

Współczesnym językiem Umberto Eco powiedzielibyśmy zatem, że odrzuca się tym samym udział intencji odbiorcy na rzecz immanentnej intencji dzieła, nad którą pełnię prerogatyw zachowuje autor ${ }^{22}$. Chociaż refleksję na temat poszczególnych składników poetyki akuminu można rozwijać znacznie szerzej, wskazując na umiejscowienie Sarbiewskiego w tradycji arystotelesowskiej, miejsca wspólne ze stanowiącym dla jezuity autorytet Scaligerem czy na stosunek do siedemnastowiecznych teoretyków konceptu, nawet tak zdawkowy opis pozwala uchwycić immanentne mechanizmy tekstowe, jakie wyrażone zostały w De acuto et arguto. Poza obszarem bezpośrednio przynależnym tradycji literackiej pozostaje kwestia umiejscowienia pointy w kompleksowej wizji rzeczywistości, która towarzyszyła autorowi.

Narzucać musi się bowiem niewątpliwie pytanie o cel, jaki stawiał konceptowi jezuicki poeta potrydencki. Nie była to teoria stworzona na potrzeby programu literackiego włoskich Marinów czy polskich Janów Andrzejów Morsztynów, których dowcip, mówiąc bardzo ogólnikowo, służył świeckiej, wyrafinowanej grze dworskiej. W profilu intelektualnym Sarbiewskiego, choć tworzył we wczesnej fazie baroku, w pierwszej ćwierci XVII wieku, zauważyć już można znamienne rysy epoki encyklopedycznej o uniwersalistycznych pretensjach, jak zwykło się widzieć stulecie Kartezjusza i Komenskiego ${ }^{23}$. Przede wszystkim autor daje się poznać już w samym traktacie $D e$ acuto et arguto jako przedstawiciel dopiero co kształtującej się, nowej epoki w dziejach nauki, która próbowała oprzeć humanistykę na mocniejszych podstawach. Sarbiewski bowiem kolekcjonuje opinie na temat pointy, a nawet sam przeprowadza „naukową ankietę”, w której zwraca się do autorytetów z pytaniem o istotę acutum. Jak stwierdza Barbara Otwinowska:

Ambicje „polskiego Horacjusza” były najwyraźniej naukowe, i to w ogromnie nowoczesnym sensie tego słowa. Jego wykład przypomina raczej pokartezjańskie analizy filozoficzne niż figuratywny język krytyki literackiej z czasów Bacona. [...] Jego pomysł naukowej ankiety [...] jest jak gdyby zastosowaniem metody eksperymentalnej na terenie nauk humanistycznych. To nie poszukiwanie autorytetu - to raczej dążenie do indukcji ${ }^{24}$.

\footnotetext{
${ }^{20}$ Por. B. Otwinowska, „Concors discordia” Sarbiewskiego w teorii konceptyzmu, „Pamiętnik Literacki” R. 59, 1968, z. 3, s. 86.

${ }^{21}$ M.K. Sarbiewski, De acuto et arguto. O poincie i dowcipie, s. 3.

${ }^{22}$ Dzieło Sarbiewskiego podatne jest na interpretację w duchu strukturalistycznych teorii literatury. Łukasz Lipiński ujmuje dzieło De perfecta poesi jako traktat narratologiczny. Zob. Ł. Lipiński, „De perfecta poesi” Macieja Kazimierza Sarbiewskiego w perspektywie wspótczesnych teorii narracji, „Meluzyna” 2014, nr 1, s. 49-64.

${ }^{23} \mathrm{Na}$ ten temat zob. C. Vasoli, Encyklopedyzm w XVII wieku, przeł. A. Anduszkiewicz, Warszawa 1996.

${ }^{24}$ B. Otwinowska, „Concors discordia” Sarbiewskiego..., s. 82-83.
} 
Polemika Sarbiewskiego nie wykazuje już zasadniczych cech agonu w renesansowej respublica literaria $^{25}$, a zbliża się, w istocie, do indukcji epoki Bacona. Dla wczesnych reprezentantów nowego stosunku do nauki podmiot poznający uwikłany jest w niełatwo przezwyciężalny dysonans między rzeczami samymi (res ipsas) a niemal z definicji zawodnymi i mylnymi opiniami o rzeczach. Krytyczna rewizja dotychczasowych poglądów, na drodze której dokonuje się praca rozumu, pozwala odrzucić próżne „idole”, zapośredniczające dostęp do „prawdy”, by oczyścić pole pod racjonalny sąd. Taka infrastruktura myślenia znamienna była w wieku XVII dla Bacona i Kartezjusza, by wymienić tyko czołowych teoretyków i naukowców. Sarbiewski podąża natomiast dopiero co rysującą się drogą poznania, by oddzielić skutki oddziaływania pointy od jej istoty, kryjącej się w uniwersalnej strukturze konceptu epigramatycznego.

Intersubiektywizm, jaki znamionował nowatorskie stanowisko Sarbiewskiego na polu krytyki literackiej, przekłada się również na dążenie do totalizującej wizji rzeczywistości, która nieuchronnie dokonywać musi się pod egidą teologii. W wykładzie o poezji doskonałej miejsce Boga i religii było wyraźnie zarysowane, zakładał bowiem Sarbiewski „istnienie ścisłej homologii między działaniem boskim i aktem kreacji poetyckiej”26, a - co za tym idzie - dokonywał deifikacji epickiego poety (alter Deus) ${ }^{27}$, który - by osiągnąć pełnię ideału - musiał być chrześcijaninem, czerpiącym z zasobów uprawomocnionego rezerwuaru „cudowności”" pochodzących od Boga, nie zaś z ludzkiej fantazji. Na tym tle De acuto et arguto zdaje się nie zachowywać tak bliskiego związku z religią, zwłaszcza że epigramat pozornie wykluczony zostaje z klasyfikacji poetyckiej podążającego za Arystotelesem autora, skoro - zwłaszcza w swojej najczęstszej formie okolicznościowej - ujmuje partykularyzmy, a nie prawdy ogólne czy „fikcję moralną" ${ }^{29}$, jest zatem „nienaśladowczy” i „afabularny”30. Poezja natomiast podług słynnej definicji Sarbiewskiego, przesuwa akcent z mimetyzmu Stagiryty na kwestie prawdopodobieństwa (verisimilitudo) i cudowności:

Poezja zatem będzie sztuką, która naśladuje byty w materiale słownym nie według tego, jak istnieją, lecz jak powinny czy też mogą istnieć, względnie prawdopodobnie [verisimiliter] istnieją, istniały lub istnieć będą ${ }^{31}$.

${ }^{25}$ Zob. K. Pomian, Przeszłość jako przedmiot wiedzy, wyd. 2 popr., Warszawa 2010, s. 128-130.

${ }^{26}$ E. Sarnowska, Teoria poezji Macieja Kazimierza Sarbiewskiego, s. 129.

${ }^{27} Z$ ob. K. Janus, Wokół pojęcia twórczości. Ze studiów nad „De perfecta poesi” Macieja Kazimierza Sarbiewskiego, „Prace Naukowe Akademii im. Jana Długosza w Częstochowie. Filologia Polska. Historia i Teoria Literatury” 2006, nr 10, s. 63-67.

${ }^{28}$ Zob. m.in. B. Niebelska, Cudowność, paralogizm, koncept, [w:] Koncept w kulturze staropolskiej, red. L. Ślęk, A. Karpiński, W. Pawlak, Lublin 2005, s. 29-47.

${ }^{29}$ Por. M.K. Sarbiewski, De perfecta poesi, sive Vergilius et Homerus. O poezji doskonałej, czyli Wergiliusz i Homer, przeł. M. Plezia, oprac. S. Skimina, Wrocław 1954, s. 20-21. Zob. również: M. Łukaszewicz-Chantry, Epigramy Macieja Kazimierza Sarbiewskiego..., s. 7.

${ }^{30}$ Zob. R. Krzywy, Poezja staropolska wobec genologii retorycznej..., s. 25.

${ }^{31}$ M.K. Sarbiewski, De perfecta poesi..., s. 4. Swoją refleksją wpisywał się Sarbiewski w zagadnienie wieloaspektowego dialogu z tradycją imitatio i mimesis, który rozgrywał się w estetyce nowożytnej od drugiej połowy XVI wieku. Najbardziej „radykalną” propozycję poetycką przedstawił Francesco Patrizi (1529-1597), który pisał, iż „wszelka poezja musi mieć za przedmiot to, co jest nie do wiary, bo ono jest podstawą prawdziwą cudowności, która powinna być głównym przedmiotem wszelkiej poezji” (cyt. za: W. Tatarkiewicz, Historia estetyki, t. 3: Estetyka nowożytna, wyd. 3 i 4, Warszawa 1991, s. 273). Zob. więcej: B. Niebelska-Rajca, Poeta imitatore czy poeta facitore? Późnorenesansowe włoskie dyskusje o mimesis, „Odrodzenie i Reformacja w Polsce” 2011, t. LV, s. 101-122. 
Jak jednak stwierdza autor w innym miejscu:

[...] niektórych epigramatów nie wyłączamy z poezji, jeśli zawierają zgrabnie przedstawione jakieś wydarzenie albo naśladowanie czyjegoś charakteru, nie takim, jakim był w istocie, ale jaki mógł byćs ${ }^{32}$.

Swoiste sprzężenie imitacji i prawdopodobieństwa, zazębiające się z definicją samej ars poetica, pozwala zatem pewnemu typowi epigramatów zachować status poezji. Sarbiewski jako praktyk nie stronił od utworów okolicznościowych, panegiryków czy stemmatów, operujących „konkretem” i „jednostkowością”, którym przyganiał Syrokomla, w obrębie jego twórczości szczególne miejsce zajmuje jednak „cykl” epigramatów religijnych Divini amores ${ }^{33}$, jakie - przyjmując ustalenia teoretyczne jezuity - można by uznać za poetyckie. Nie miejsce tu na omówienie złożonej problematyki konceptycznych epigramatów o miłości bożej inspirowanych Pieśniq nad pieśniami, które mimo niewątpliwie zawartej w nich „fikcji moralnej” w nie mniejszym stopniu spotykały się z zarzutami o przekraczanie klasycystycznych granic smaku na skutek zastosowania „dowcipu" do materii religijnej ${ }^{34}$. Praktyka poetycka Sarbiewskiego pozwala jednak rzucić pewne światło na znaczenie metafizyczno-poznawcze, jakie kryć mogło się w epigramatycznej poincie.

W De acuto et arguto przedstawia się trójkąt jako uniwersalny model konstrukcji akuminu, pewne wątki refleksji autora z traktatu Dii gentium (Bogowie pogan), stanowiącego „podsumowanie renesansowej mitografii” ${ }^{35}$, pozwala natomiast zauważyć związek między figurą geometryczną i analogiczną do niej bryłą stereometryczną a zasadą porządkującą rzeczywistość. W kontekście religii starożytnych przemyca bowiem Sarbiewski ciekawą refleksję:

Jeśli zaś wzięli pod uwagę naturę samego Boga w zestawieniu ze światem, dowodzili, że Apollo, czyli Bóg, jest ostrzem piramidy, tj. punktem, z którego idą i znów do którego wracają wszystkie linie całej piramidy, czyli świata, chociaż sam punkt jest zupełnie niepodzielny i jak Bóg zupełnie niedostępny dla wzroku, gdy tymczasem cała piramida jest widzialna ${ }^{36}$.

Dochodzi tutaj autor do konstatacji pewnej „zasady kosmicznej”37, według której świat przypomina widzialną piramidę, jej wierzchołek (acutum) stanowi zaś Bóg, przez pogan utożsa-

${ }^{32}$ M.K. Sarbiewski, De perfecta poesi..., s. 21.

${ }^{33} \mathrm{Nie}$ ma zgody wśród uczonych co do kształtu cyklu, nie zachował się bowiem żaden manuskrypt, który naprowadzałby na autorską organizację utworów. Wiadomo jedynie, iż Divini amores były dedykowane w 1623 roku Tarkwiniuszowi Galluzziemu, sporne pozostaje natomiast wyodrębnienie epigramatów cyklu z większej całości, jaką jest Epigrammatum liber. Na ten temat: M. Piskała, D. Sutkowska, Wprowadzenie do lektury, s. 11-12; A. Kołos, „Fides quaerens intellectum”..., s. 96-103.

${ }^{34} \mathrm{~W}$ dawniejszej tradycji badań literackich powszechny był sceptyczny stosunek do stosowania konceptu w tematyce religijnej. Stefan Zabłocki dostrzegał w tym „komizm” i „świętokradztwo” (S. Zabłocki, Od prerenesansu do oświecenia. Z dziejów inspiracji klasycznej w literaturze polskiej, Warszawa 1976, s. 178). Claude Backvis Stanisławowi Herakliuszowi Lubomirskiemu jako autorowi opartych na koncepcie Poezji postu świętego zarzucał „świeckie figle” (,Osobność” jako temat w twórczości i osobowości Stanisława Herakliusza Lubomirskiego, [w:] Stanisław Herakliusz Lubomirski. Pisarz - polityk - mecenas, red. W. Roszkowska, Wrocław 1982, s. 38). Krystyna Stawecka nie unikała natomiast wartościujących sądów estetycznych nad „barokowością” stylu Sarbiewskiego, w kontekście Divini amores orzekając o nieprzystawalności Pieśni nad Pieśniami do „popisów w zakresie akuminu" (K. Stawecka, Maciej Kazimierz Sarbiewski. Prozaik i poeta, Lublin 1989, s. 180). Więcej o problemach estetyki barokowej i ocenach badaczy: E. Buszewicz, Sarmacki Horacy i jego liryka..., s. 85-91.

${ }^{35}$ P. Urbański, Theologia fabulosa..., s. 29.

${ }^{36}$ M.K. Sarbiewski, Dii gentium. Bogowie pogan, wstęp, oprac. i tłum. K. Stawecka, Wrocław 1972, s. 277-278.

${ }^{37}$ Por. J. Bolewski, Nascitur una... discors concordia. Aspekty teologiczne twórczości Sarbiewskiego, [w:] Nauka z poezji Macieja Kazimierza Sarbiewskiego SJ, red. J. Bolewski SJ, J.Z. Lichański, P. Urbański, Warszawa 1995, s. 107-108; M. Łukaszewicz-Chantry, Epigramy Macieja Kazimierza Sarbiewskiego..., s. 13. 
miany z Apollem. Analogia ta pozwala dostrzegać w strukturze epigramatu, opartego na trójkącie wraz z całym bagażem symboliki liczby „trzy”, odwzorowania porządku świata. Poza sferą ,intuicji przedchrześcijańskich”38, śledzonych w dziedzictwie antyku, podobnych tropów dostarcza interesująca, „konceptyczna” refleksja nad nadrzędnym dogmatem katolickim:

Owe bowiem trzy kolory tęczy wydają mi się doskonale wyrażać niektóre właściwości osób Boskich, tj. błękit owej nie stworzonej Irydy odpowiadałby Bogu Ojcu, zieleń - Duchowi Św., kolor żółty - Synowi. Jak bowiem dokładne oświetlenie błękitu osiąga się w sposób właściwy przez kolor żółty, tak Syn jest światłem Ojca i blaskiem Jego istoty, gdyż jest słowem Ojca i kresem owego poznania, w którym Ojciec sam się sobie ujawnia, sam siebie poznaje i w jakiś sposób sam się sobie wyjaśnia. Znowu tak jak zieleń jest w istocie swej barwą pośrednią pomiędzy niebieską a żółtą i istnieje ich jakieś zjednoczenie i miłość, a ściśle mówiąc (zieleń) powstaje z błękitu i barwy żółtej, tak Duch Św. jest zjednoczeniem i miłością Ojca i Syna i od nich całkowicie pochodzi. [...] Dlatego spośród wszystkich rzeczy stworzonych, uczynionych sztuką i przez naturę, ów znany powszechnie szklany trójkąt, przez który widać wszystko zabarwione tymi trzema kolorami, wydaje mi się być najpiękniejszym symbolem Trójcy Św., i sam bowiem kształt trójkąta, i owa potrójność barw dziwnie, jak powiedziałem, zgadza się z Trójcą Św. Bym już zamilczał, że przez Trójcę Św., i sam bowiem kształt trójkąta, dostrzega się trzy barwy każdej rzeczy stworzonej i jakby linie rozproszone i światła: błękit, tj. potęgę Ojca, kolor żółty, tj. mądrość Syna, zielony, tj. dobroć Ducha Św., albo z oglądania Jej atrybutów w stworzeniach, wiadomo, że rodzi się miłość ku Bogu, nic bowiem nie jest tak bliskiego, gdy poznasz Boga, jak byś Go pokochał ${ }^{39}$.

Relacja między Bogiem Ojcem, Synem a Duchem Świętym została we fragmencie Dii gentium opisana niemalże w terminach gramatyki epigramatycznego konceptu, w której dwie linie trójkąta jednoczą się w punkcie przecięcia (acutum) ${ }^{40}$. Z jednej strony, tęczę uznaje autor za naturalny fenomen ilustrujący właściwości Trójcy, z drugiej wskazuje na „szklany trójkąt”, czyli zapewne pryzmat rozszczepiający światło, jako na doskonały wytwór człowieka, który zdaje się imitować naturę. Sarbiewski tworzył w okresie, w którym uważano jeszcze, iż to sam pryzmat zabarwia jasne światło, dopiero zaś eksperymenty Newtona przeprowadzane od 1666 roku, fundatorskie dla nowożytnej spektroskopii, udowodniły, że kolor stanowi inherentny składnik światła, a fundamentalny wykład teorii opublikowany został w 1704 roku jako Opticks. Jednakże już średniowiecznym zagadnienie to nie było obce. Żyjący na przełomie XII i XIII wieku Robert Grosseteste uznawał, że tęcza stanowi wynik refrakcji promieni słonecznych, a eksperymentami z pryzmatem parali się również w XIII wieku Albert Wielki i Roger Bacon, a wreszcie jeden z najważniejszych uczonych optyków średniowiecza, pochodzący ze Śląska Witelon ${ }^{41}$. Źródła erudycji Sarbiewskiego z zakresu filozofii naturalnej domagałyby się badań przeprowadzonych przez historyków nauki, które mogłyby wskazać, czy

${ }^{38}$ P. Urbański, Theologia fabulosa..., s. 30.

${ }^{39}$ M.K. Sarbiewski, Dii gentium. Bogowie pogan, s. 163.

${ }^{40} \mathrm{Na}$ ten temat zob. również: A. Kołos, Trójkąt jako matematyczny wzór świętości. Metafizyka konceptu Macieja Kazimierza Sarbiewskiego, [w:] Obraz świętości - świętość w obrazie, red. I. Lis-Wielgosz, W. Jóźwiak, P. Dziadul, Poznań 2014, s. 186-188.

${ }^{41}$ W XII wieku w Europie krążyć zaczęły łacińskie przekłady Meteorologii Arystotelesa, co wywarło duży wpływ na średniowieczne próby wytłumaczenia tęczy, rozpoczęte przez Grosseteste'a. Naukę europejską wyprzedzał jednak Alhazen, arabski uczony przełomu X i XI wieku, którego praca na temat optyki przełożona została na łacinę około 1250 roku. Z jego osiągnięć korzystał już Witelon. Zob. więcej: R.C. Dales, Studies of the Rainbow, [w:] tegoż, The Scientific Achievement of the Middle Ages, wyd. 6, Philadelphia 1994, s. 81-88. 
zagadnienie rozszczepienia światła znał jedynie ze źródeł średniowiecznych, czy też - a jeśli, to do jakiego stopnia - korzystał ze współczesnej mu wiedzy ${ }^{42}$.

Ujmując jednak materię nauki w nawias, wypowiedź Sarbiewskiego wprowadza zasadniczą hierarchię między naturą, stworzeniem a sztuką, które przekłada się również na kreacjonistyczną teorię poezji. Jeśli podług kategorii scholastycznych Trójcę uznać należy za natura creans, to tęcza jako zjawisko przyrodnicze odpowiada pojęciu natura creata, a ich „doskonałym” naśladownictwem okazuje się pryzmat, stanowiący jednocześnie wytwór sztuki i imitację natury. Na polu poezji epigramat, tworzący i odtwarzający harmonię przeciwieństw, stanowi analogon szklanego przedmiotu, w obu przypadkach jednak wyraźnie Sarbiewski podkreśla element kreacji, nieograniczającej się do prostego naśladownictwa. Fingere et imitari czy creare et condere oznacza bowiem w barokowej poetyce, iż poeta imituje stwórczą moc Boga ${ }^{43}$. Tak rozumiany koncept nie jest zatem wyszukaną grą słów, lecz stanowi akt poznania „kosmicznego" dowcipu zawartego w dziele stworzenia. Ponadto, w kontekście autorskiego cyklu Divini amores istotne wydaje się spostrzeżenie z Dii gentium, iż poznanie Boga prowadzi bezpośrednio do miłości, a co za tym idzie, można sądzić, iż poeta jednocześnie próbował afektywnie wzbudzić przez akt epistemiczny mistyczne uwielbienie. Teoretycy akuminu w drugiej połowie XVII wieku obraz Boga jako doskonałego konceptysty wyrażać będą jeszcze dobitniej, sam Emmanuele Tesauro, autor Il cannocchiale Aristotelico (1654), orzeknie: „Cokolwiek bowiem na świecie jest dowcipnego, jest albo samym Bogiem albo od niego pochodzi”44.

Sarbiewski być może nie formułuje tej myśli równie jednoznacznie, lecz - jak wskazują fragmenty Dii gentium - w symbolu trójkąta lub przestrzennego ostrosłupa dostrzega pewną „dowcipną” tajemnicę Boga i stworzenia, a zaproponowana przez niego uniwersalna struktura epigramatu odtwarza tę kosmiczną zasadę. W innym miejscu traktatu mitograficznego autor daje kolejny wyraz przeświadczeniu o homologii między niezgodną zgodnością konceptu a porządkiem świata:

Cytra, którą na starożytnych posągach nosi Apollo, oznacza ową harmonię, przy pomocy której Bóg zachowuje świat i niezgodną zgodność [discordem concordiam] według starożytnego poety: „Rządzisz całym Olimpem przy pomocy cytry”. Wspaniale to wyraził Klemens Aleksandryjski, traktując o mistycznej pieśni Słowa Bożego: „To dla ciebie”, rzecze, „i uporządkował rytmicznie i harmonijnie wszechświat, i niezgodę elementów sprowadził do porządku zgodności, aby mu cały świat stał się harmonią" ${ }^{35}$.

\section{Zakończenie}

Poetyka sformułowana Sarbiewskiego to nie tylko zbiór normatywnych reguł barokowego smaku, który dla potomnych stanowić może jedynie świadectwo druzgocących zmian w literackich gustach epoki. Nawet jeśli zgodzić się, iż twórczość siedemnastowiecznych poetów minorum gentium wraz z kontynuacją nurtu w epoce saskiej sprawiła, iż Dmochowski miał uzasadnione

\footnotetext{
${ }^{42} \mathrm{~W}$ epoce Keplera i Galileusza zagadnienie światła było szczególnie silnie związane z problematyką konstrukcji teleskopów. Dopiero lata czterdzieste XVII wieku przynoszą publikacje z zakresu spektroskopii (Atanasius Kircher, Jan Marek Marci).

${ }^{43}$ Por. K. Janus, „Poesis - universi pictura”. Rozważania na temat twórczości Macieja Kazimierza Sarbiewskiego, „Świat i Słowo" 2011, nr 1 (16), s. 175-176.

${ }^{44}$ Cyt. za: W. Pawlak, Koncept w polskich kazaniach barokowych, Lublin 2003, s. 79.

${ }^{45}$ M.K. Sarbiewski, Dii gentium. Bogowie pogan, s. 265. Zob. również: J. Bolewski, Nascitur una... discors concordia..., s. 106.
} 
powody do utyskiwania, że „dawniej epigrammatów duch się zbyt rozszerzył”, twórczość wczesnobarokowego jezuity swoim rozmachem wykracza daleko poza „sprawę smaku”. Z perspektywy historii europejskich formacji intelektualnych profil Sarbiewskiego ukazuje znamiona epoki przejściowej pomiędzy renesansem, którego episteme opierała się na zasadzie odwzorowania, postulującej wielki ciąg analogii słów i rzeczy ${ }^{46}$, a nowym paradygmatem nowożytnej wiedzy. Z jednej strony, u autora dostrzec można - co sugerowała już Otwinowska - sygnały obiektywistycznej, opartej na indukcji metody dowodzenia, które zbliżałyby go do świadomości Bacona czy Kartezjusza, jego zacięcie encyklopedyczne wskazuje na zakorzenienie w myśli aktualnej dla XVII wieku, a predylekcja do posługiwania się figurami geometrycznymi świadczy o rosnącym autorytecie matematyki w dobie rewolucji naukowej. $Z$ drugiej jednak, uniwersalistyczna wizja świata $\mathrm{z}$ uprzywilejowaną w hierarchii poznania poezją zdradza ciągłą bliskość stopniowo mijającemu paradygmatowi „wielkiej księgi natury”. W tym aspekcie Sarbiewski pozostaje przynależny epoce Galileusza i Keplera, którzy nowatorskie badania naukowe prowadzą wciąż, opierając się na wielkich narracjach o rzeczywistości. Jak pisał włoski astronom w Il saggiatore (1623):

Filozofia zawarta jest w tej przeogromnej księdze, którą ciągle mamy otwartą przed oczami (nazywam tę księgę wszechświatem), nie można jednak jej pojąć, jeśli wpierw nie pozna się języka, i nie pozna się liter, w których została ona zapisana. A księga ta została napisana w języku matematycznym, i jej literami są trójkąty, koła i inne figury geometryczne; bez tych środków niemożliwe jest dla człowieka zrozumienie słowa zapisanego w tej księdze; bez nich udziałem człowieka jest próżne błąkanie się po ciemnym labiryncie ${ }^{47}$.

Wydaje się, że dla Sarbiewskiego to poezja zawarta jest w księdze świata, której język ciągle służy odwzorowaniu konceptów i rzeczy. Z kolei przywiązanie do kategorii kosmicznej harmonii, nawet jeśli nieco zredefiniowanej w duchu poetyki akuminu, znajduje swoją analogię w myśli Keplera, który przełomowe odkrycia ruchów planet i szczegółowe refleksje na temat wielościanów wyraził w dziele o znamiennym, wiele mówiącym tytule Harmonices mundi (1619).

Twórczość teoretyczna Sarbiewskiego operująca wielowarstwowością refleksji literackiej, estetycznej, kosmologicznej i epistemicznej nie powinna być relegowana jedynie na pole dawnych poetyk normatywnych. Stanowi natomiast zbiór tekstów, które dzięki lekturze w kluczu historii idei, odsłania zaplecze intelektualne i dążenia poznawcze podmiotu przynależącego do fascynującej epoki nieznającej jednoznacznych podziałów dyscyplinarnych. Chociaż klasycystyczny smak oświecenia, a następnie liryka romantyczna na trwałe zmieniły stosunek współczesnych do poetyki barokowej, dla historyków szeroko pojętej kultury dzieło Sarbiewskiego zachowuje niesłabnącą atrakcyjność. Być może - z przymrużeniem oka - podobnie można powiedzieć o samym symbolu, który autor wiązał z konceptem, skoro na okładce kultowej płyty Pink Floyd The Dark Side of the Moon (1973) pojawia się pryzmatyczny trójkąt rozszczepiający światło na kolory tęczy, idealna ilustracja łącząca (concipere) myśl z De acuto et arguto oraz Dii gentium.

\footnotetext{
${ }^{46}$ M. Foucault, Stowa i rzeczy. Archeologia nauk humanistycznych, przeł. T. Komendant, wyd. 2, Gdańsk 2006, s. 29 i n.

${ }^{47}$ Galileo Galilei, Waga probiercza, [w:] T. Sierotowicz, Od metodycznej polemiki do polemiki metodologicznej. Impresje z lektury „Wagi probierczej” Galileusza wraz z antologiq, Tarnów 2008, s. 133-134.
} 


\title{
SŁOWA KLUCZOWE:
}

\section{estetyka}

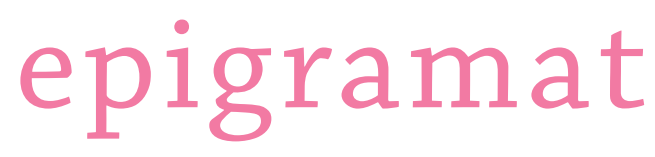

$$
\text { p o i n t a }
$$

\section{koncept}

\begin{abstract}
Abstrakt:
Twórczość teoretyczna Macieja Kazimierza Sarbiewskiego, cieszy się stałym zainteresowaniem badaczy, którzy najwięcej uwagi poświęcają problematyce koncepcji i estetyki poezji, chrystianizacji antyku czy imitacji horacjańskiej. Wieloaspektowa refleksja autora przynależącego do „przejściowej” formacji intelektualnej w dziejach europejskiej myśli zachęca jednak równie silnie do studiów z zakresu historii idei, które sytuują przedmiot poznania na styku zautonomizowanych dziedzin nauki. Traktat De acuto et arguto poświęcony konceptycznej strukturze epigramatu, stanowi nie tylko świadectwo barokowej teorii literatury, lecz również, czytany w dialogu z innymi pismami Sarbiewskiego, odsłania konsekwentną kosmologię rzeczywistości.
\end{abstract}




\title{
SARBIEWSKI
}

\author{
poetyka sformułowana
}

barok

HISTORIA IDEI

\section{NOtA O AUTORzE:}

Anna Kołos (ur. 1987) - doktor nauk humanistycznych w zakresie literaturoznawstwa. Pracę doktorską pt. „Sceptycyzm w literaturze polskiego baroku” obroniła w 2015 roku na Wydziale Filologii Polskiej i Klasycznej Uniwersytetu im. Adama Mickiewicza w Poznaniu. Jej główne zainteresowania obejmują dawną kulturę intelektualną i historię idei ze szczególnym uwzględnieniem związków literatury z filozofią, dyskursem naukowym i religią. Ponadto zajmuje się imagologią, badaniami nad monstrualnością, geografią mentalną i wizerunkiem „obcych” kultur w piśmiennictwie. W 2013 roku opublikowała książkę pt. „Fides quaerens intellectum". Wiara i rozum w barokowym konceptyzmie Macieja Kazimierza Sarbiewskiego i Stanisława Herakliusza Lubomirskiego. 